\title{
Maqasid Shariah in the Guidelines for Iddah of Women upon Husband's Death
}

\author{
Fatimah Salleh$^{1}$, Noorul Huda Sahari1 ${ }^{*}$, Siti Khadijah Ab Manan', \\ Che Zahrah Abdullah ${ }^{1}$, Zaharah Yahya ${ }^{1}$ \\ ${ }^{1}$ Akademi Pengajian Islam Kontemporari, Universiti Teknologi MARA, \\ 40450 Shah Alam, Selangor, Malaysia \\ ${ }^{*}$ Corresponding Author \\ nooru088@uitm.edu.my \\ Received: 4 June 2020 \\ Accepted: 20 August 2020 \\ Online First:
}

\begin{abstract}
Iddah is a period of mourning for a woman whose husband has passed on during which time she has to adhere to certain rules set by the Islamic law. Adherence to this rule is a form of devotion for the preservation of lineage and descent while at the same time expressing sadness. In addition, this order has also been applied to protect the welfare and rights of women after the death of the husband. Adherence to certain laws and regulations by women whose husband has passed away, has long been outlined by Islamic scholars. However, the reality of today's life requires many women to leave home for work or other family-related matters. This scenario creates a polarization in society where a woman whose husband dies needs to mourn and at the same time meet the needs of the family. The general public is still unclear. The implementations and practices are seen as inconsistent and not uniformed due to their misunderstandings and possibly even confusion of their practices during this mourning state of iddah. This study aims to identify the rules to be followed for women whose husband has passed on, with regard to dressing, travelling, and practising with their co-workers in accordance with shariah or maqasid shariah objectives. This study uses qualitative method based on two approaches, namely doctrinal mazhab method based on contemporary sects and figh approaches. The findings
\end{abstract}

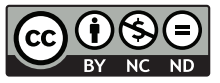


of this study indicate that there is a need for more detailed guidelines and waqi'e within the scope of the syariah jurisprudence for community reference in adhering to the rules and laws of the state. This takes into account the current contexts in order to avoid misunderstandings or confusion among the public.

Keywords: Iddah, Maqasid Syariah, Women of Iddah

\section{INTRODUCTION}

Islam protects women's status and dignity by respecting their rights during and after marriage. The wife of the husband who has passed on has been ordained to mourn without adorning herself in certain circumstances and periods. Therefore, after the death of the husband, the wife should maintain the relationship with good behaviour such as avoiding wearing beautiful and attractive clothing as well as decorating and putting on fragrance when going out of the house like other women. Thus, the demands of the Islamic intercession are an order and worship to protect the honour of widows who have lost their spouses.

Iddah (mourning) in Arabic is al hadaad (الْحَدَادُ) (Mahmud Abdul Rahman, 1999) that is, not putting on accessories in terms of attire that is attractive that renders others towards matrimony (Ibni Hajar, n.d.). Other opinions state that al hadaad is the attitude of a woman who does not wear everything that can attract others to marry her such as perfumes, eyelashes and attractive clothing and does not leave the house without urgent need, after the death of her husband (Muhammad Al Hamuud An Najdi, 1415H). According to Kamus Dewan, mourning is a sign of sorrow over the death (Teuku Iskandar, 2007).

Iddah also implies that a woman is forbidden to adorn herself and that she means only to express her sadness. This is in verbal al-'Arab, al-Misbah al-Munir and Mukhtar al-Sihah in the word "حَدَد". A woman is forbidden to adorn and she brings to her the same meaning at certain times in certain circumstances. This also includes avoiding overnight stay other than her home (Fath al-Qadir, (3/293), Ibn 'Abidin, (2/616), al-Khattab, (4/154), Nihayah al-Muhtaj, (7/140) \& al-Mughni li Ibn Qudamah, (9/166)). 
In this regard, this study aimed to identify the level of understanding of Muslim women on the concept of Iddah, the period of Iddah, and the wisdom of its practice in Islam. The study also focused on the rules and prohibitions of women who lost their husbands in the matter of dressing while travelling, while in muamalah and in muasyasyah with their co-workers in accordance with maqasid shariah. This study can provide comprehensive guidelines based on the Qur'an, hadith and fiqh of previous and contemporary scholars. In addition, this study will help the women of the Islamic world to carry out the iddah as commanded by shariah without neglecting the requirements of life based on the maqasid shariah.

\section{THE CONCEPT OF IDDAH AND ITS CHALLENGES}

The concept of Iddah and its related matters should be known to every woman. However, there is still confusion and misunderstanding in society today to practise it namely:

1. When does iddah start for a woman, is it appropriate for a wife whose husband has passed away to participate in the management of her husband's funeral and burial rites as it is common in today's society?

2. Are the rules prescribed by shariah being understood and obeyed by the wives, not excessive and not relaxing / ignoring the law and even practising lawless superstition?

3. Re-evaluate some terms in the concept of iddah such as 'emergency matters', subdued clothing, travel ban and many more

There are various views on the issue of iddah which has become widespread on various social media. It is hoped that this study will provide clarification for the Muslim community, in particular among Muslim women who are undergoing a period of iddah and mourning so as to make it easier and more comfortable while avoiding slander, persecution and other unpleasant elements towards women in Iddah. It is also hoped that this study will help the community to better understand and appreciate the concept of iddah and mourning according to the actual demands of Islam. 


\section{Differences in Views of the Iddah Related Sect}

1. Law on Iddah

Islamic scholars have agreed on the obligation of women at the death of the husband (Ibn Al Qayyim, the Shaykh of al Arnauth and Abdul Qadir al Arnauth, 1421H). Iddah for a woman whose husband dies is 4 months 10 days and is included in the number of iddah is the law of mourning (in sorrow) for the wife. This is according to the words of Allah al Mighty:

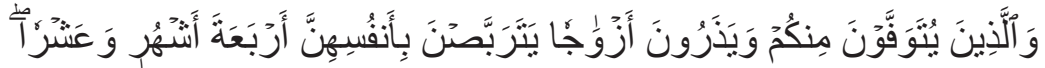

Meaning: Those who die among you by leaving their wives (let them) postpone (iddah) four months and ten days.

(Al-Baqarah: 234)

If the wife of her husband dies, while she is pregnant, then the iddah is until the woman gives birth to her child. This is according to the words of Allah Almighty:

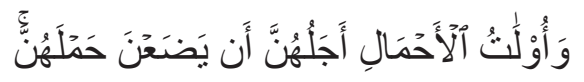

Meaning: And pregnant women, their time of conception is until they give birth.

(Al-Talaq: 4)

2. Place of Settlement

During the iddah and mourning of the husband's death, a woman is banned from leaving her home except in an emergency or in need for a purpose. It was based on the words of the Prophet (pbuh) to Furay'ah binti Malik bin Sinan when asking the question, is it possible for her to return to the place of a family member, Bani Khudrah for the death of her husband. Then His Highness Rasulullah (pbuh) replied: 


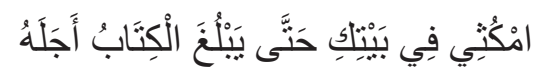

Meaning: Be steadfast in your house until it is so determined.

Riwayat Abu Daud (2300) \& Al-Tirmizi (1204)

Furay'ah R.A. completed her iddah for four months and ten days and during the reign of Caliph Uthman bin' Affan RA, he sent someone to inquire about the event and Furay'ah told about the event and the Caliph Uthman RA followed and adhered therein. Al-Imam alKhattabi states that according to the above hadith, for a woman whose husband died, she should have been at her husband's house and could not leave the house except in an emergency and for a purpose. This is also the opinion of al-Imam Malik, al-Thauri, al-Shafi'e, Ahmad and Muhammad bin al-Hasan Rahimahumullah (Ma'alim al-Sunan. 3/287).

Ibn Abd al-Bar explained that a woman whose husband has passed away should be held in the house where she lives, either hers or her husband's. It is not possible for her to complete her iddah except in the house and this is the opinion of al-Imam Malik, al-Shafi'e, Abu Hanifah and the followers, al-Thauri, al-Auza'ie, al-Laith bin Sa'ad and Ahmad bin Hanbal Rahimahumullah (al-Istizkar, 6/214).

The conclusion is that women should not rush out of their home unless there is an emergency or a need for intentions allowed by the law. They cannot even go out to perform the umrah before a completed iddah. All four mazhabs also agreed to ban women from going out to perform pilgrimage. Saidina Umar RA once called home women whose husbands were dying to perform the pilgrimage at Dzu alKulaifah until they started praying at their home. (al-Mughni, 8/168 \& al-Majmu ') In Malaysia, the Pilgrimage Board has determined that a woman who has obtained her husband's consent to perform her hajj, but before she could leave, her husband died and the woman could not go out to perform the pilgrimage because she is in accordance with Syariah and she is refused to leave the house (Qur'an, Umrah and Pilgrimage Questions 2015). 
3. Accessorising and Fragrance.

Women who are currently in mourning are banned from decorating or adorning other things that may attract men.

The Prophet said:

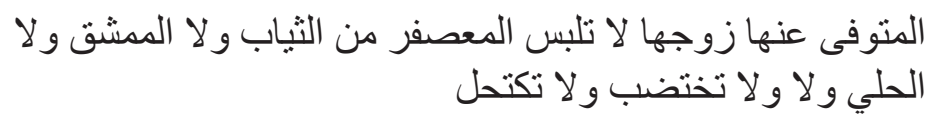

Meaning: A woman whose husband dies cannot wear clothes dyed in red (red), clothes dyed in yellow or red, wearing jewelry, hair or body colouring (with henna or something else) and wearing makeup."

(Hr Ahmad, Abu David and others)

Ummah Atiah (Friend of the Prophet SAW) said:

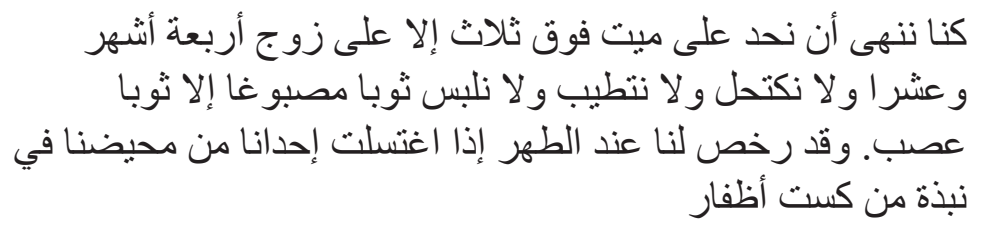

Meaning: We were forbidden by the Prophet (pbuh) to mourn over a person's death for more than three days except for his wife. It is mandatory to mourn for four months and 10 days. For that long we are not allowed to line our eyes. We were allowed to put on the fragrance, put on attire dyed in colours except cloth of asab (materials from Yemen). We are permitted to put on a bit of fragrance made from frankiscence and azafar after we have to bathe after running out of menstrual blood.

(HR Bukhari and Muslim).

In the book of Mausuah Feqhiah, it states:

"A woman who mourns her husband's death should abstain from every thing considered jewellery in terms of syara or customary, whether 
it is on her body and clothing, which appeals to others' views such as going out of the house or receiving a matrimonial proposal." This is agreed upon by Islamic scholars (Sobuni, Syarbini, Muhammad Zuhaily, Ibn Hajar Asqalani)

According to Mazhab Syafie's view, what is forbidden to women during pregnancy is:

(a) Colour dyed clothing for accessory purposes. It must be the original coloured cloth. Wearing any type of fabric is allowed as long as it is not coloured in any other colours. Cloth dyed in other colours not for accessory purposes such as black is allowed.

(b) It is illegal to wear jewellery such as rings and such made of gold, silver and gems.

(c) It is illegal to wear fragrance on the body, clothing, food and skin. as well as other acts that are considered alluring in the eyes of the local community.

The ban refers to what is considered jewellery and not to cleaning. Cleanings such as bathing, brushing and so on are allowed.

\section{Maqasid Syariah in Iddah Legal Implementation (Mourning)}

1. Expression of loyalty and celebrating husband's rights

A holy marriage bond should never be forgotten. It is unreasonable that after the death of the husband, the wife wears beautifully decorated clothes and fragrances and then leaves the house like any other women. It does not convey any tribute to her deceased husband. Thus, scholars and the imams of the four mazhabs have concluded that the obligation during iddah is to express sorrow and to fulfill promise. Likewise, it is because of the loss of marriage and not only of worldly pleasure, but also of the afterlife. This is because, marriage is the reason for their success in this world and in the hereafter. 
2. The same is true of the objective to prevent the intention of a man to be with the new widow, because if she is adorned she is certainly led in to this direction and this is not allowed at all (Syarh Fath al-Qadir, $3 / 29)$

Although the law regarding women's idiosyncrasies seems to impede women's liberty, it actually benefits the woman. The purpose of the inquiry is to ensure that their interests are protected. Among the aspects of the benefit of the inquiry are:

(a) Guaranteeing the Purity of the Lineage

Islam places great concern on the care of lineage or descent. It is included in al-daruriyyat al-khams (Abd al-Wahab Khalaf, 1956) which must be maintained for the well-being of human life. The practice of iddah is actually aimed at cleaning a wife's womb before the new marriage takes place. In other words, iddah can determine the fate of the foetus if the woman is pregnant after the death of the husband (Sa'ad Yusuf Mahmud Abu 'Az i $z$, (n.d.). This is because during the period of iddah, women are not allowed to marry any man. If she is pregnant, the contents of her relationship with the deceased husband and the child to be borned can be attributed to the husband. This situation is important to prevent the mixing of female lineage. The period of iddah prescribed by shariah is in line with the scientific facts of the formation of the foetus. According to science, when the foetus is 16 to 20 weeks old, the foetus begins to move in the womb (Curtis, 1994). The formation of the foetus by that time has reached an almost perfect stage of limb formation. Key members including the feet, hands, fingers, ears and genitals have been perfectly formed (Michele Isaacs Gliksman \& Theresa Foy DiGeronimo, 1999). This fact is also acknowledged by an authentic hadith explaining that the foetus is formed through three stages. First, the combination of semen takes 40 days. Second, a single drop of blood for 40 days. Third, a small amount of meat during the same period. After the three phases of foetal formation, the angels will breathe the soul of the foetus (Abu Zakariyya Yahya Syarf al-Nawawi, (2001). This is less than 
Maqasid Shariah in the Guidelines for Iddah of Women upon Husband's Death

ten days from the total number of days in the period of iddah. However, according to Ibn Kathir, the addition of ten days is a cautious step (al-ihtiyat) (Ibn Kathir, (1998).

\section{(b) Protecting Woman's Dignity}

Amongst members of society, there is a presence of cynicism in associating widows with negative issues (Kamarul Azmi Jasmiet al., 2004). In due course, at times they are accused of various slanderous acts that defile women in the iddah. Thus, the dissemination of iddah is one of the alternatives to counteract the negative public perception upon the widow. They are forbidden to leave the house without intent and are forbidden from being seen by any man openly. The ban is therefore very relevant to today's challenging situation and reality.

\section{METHODOLOGY}

This study aimed to identify the rules that need to be followed for women whose husband has passed away. It is intended to get responses from women who have undergone the death of their husband and about their approach to cope and to live up to it. To achieve this aim, the study adopted qualitative approach using two methods such as the doctrinal method and the interview method. The doctrinal method is through a library study where the source of information related to this study is obtained from the library books, articles and online data from the library. Meanwhile, the information on interview method was taken from the respondents' interviews of 15 women who have undergone the death of the husband during the stipulated period and were randomly selected from various ages, educational backgrounds and careers including housewives. This study also took the expertise of experts in the field of marriage jurisprudence including matters related to iddah. For this purpose, structured and face-to-face interviews with observational methods were also conducted. 


\section{FINDINGS AND DISCUSSION}

Based on the interviews of respondents selected from the experts and women whose husbands have passed away, the findings of this study are summarized as follows:

1. The Experience during Iddah and its Challenges

Sadness is a common reaction to death. Crying indicates that the person is expressing sympathetic reaction and needs protection from the people around her. Prolonged tears show profound sadness (Parkes \& Prigerson, 2010). This view is in line with the findings of the study, in which all the respondents interviewed explained that the period of iddah is very much a daily life and requires a lot of patience and perseverance as well as very much needs help from various parties. One of the respondents, who is a lecturer at a public university currently on study leave, had one year of depression. Among the disturbance include hearing the voice calling her name, speaking alone, constantly disturbed and unable to live alone. The action she took was to return to her hometown and stay with her family. Depression can be overcome by going shopping and buying expensive clothes to satisfy her needs. Besides, decorating the house with great sincerity, all these efforts are made to restore happiness and joy.

Another respondent, who is a homemaker, thought losing her husband has made her lose her place. In addition, his death occurred suddenly due to a heart attack. During her period of iddah, she did not leave much of the room, as her husband's business was taken over and was managed by her son. To ease her sadness, she contacted her closest friends and organized religious studies classes at home. This would enhance her home life as she could interact with her classmates without ever having to leave the house.

In addition, she did not go to the cemetery to accompany her husband's body on the grounds that there was no need to do so and to maintain her honour. She only went to visit her husband's grave after her iddah. 
The next respondent was Ustazah Zawiyah Hassan, former Chief Assistant Registrar of Marriage, Divorce and Referral (NCR), Islamic Religious Department (JAWI), Kuala Lumpur. She did not attend the mosque to bathe her husband and did not attend her husband's burial ceremony. She thinks that such a time is more appropriate for a wife's iddah began after the death of her husband, and that it was not necessary for a wife to be present at the funeral. She only visits the cemetery after the expiration of her iddah period of four months and ten days.

According to her, the main obstacle during iddah are matters relating to sensuous desire and problems relating to the heart and feelings. She argues that many women who have undergone iddah after their husbands' death do not comply with Islam, in accordance with the Islamic law. Ignorance is a major factor in the symptoms. She cites a very common example in society where a child would bring a mother home, while the latter is undergoing iddah, home to her child and spend the night at the child's home, for the purpose of consoling a grieving mother. Ustazah Zawiyah suggested that children should stay overnight at their mothers' homes, not vice versa. She also argues that the prohibition against women undergoing iddah is not opposing against women, as the goals of iddah are part of the needs to fulfill the demands of maqasid syariah.

2. Suggestions from the Respondents

(a) The findings show that $100 \%$ of respondents recommend that a career-oriented woman whose husband has passed away should be granted a leave of absence. Significant changes in a wife's life require physical and spiritual recovery and family support. According to Azlina, women are more at risk of depression because of the social psychological factors of Eve who are overly concerned about something profound. "For example, when women are experiencing household problems. Women will think about why, why, why and how the problem happened" (Cosmo Online, 2018). 
(b) $93 \%$ of respondents also suggested that women should gain more exposure to iddah-related knowledge because all married women have the potential to go through that era. If they are not destined to become widows, they have family and relatives and friends who will experience it. There are even groups of women who feel they are no longer relevant to practise iddah in this modern age. In one survey, $13.1 \%$ of the total respondents said that iddah was no longer practised, while $23.1 \%$ had reacted somewhat to the obligation (Syh. Noorul Madihah Syed Husin, 2007). Although the percentage is not very high, such statements do not necessarily occur in the Muslim community, as it reflects negative perception of Islamic law.

(c) There are various ways in which those who are dedicated to adjust to the new world are doing so. $87 \%$ of respondents have done various activities to bring themselves closer to the Creator. There were respondents who made their home a place for study classes, holding yasin majlis and Quran reading activities. In addition, there are also other approaches to increase religious knowledge by listening to religious talks through youtube and other communication tools. The study found that respondents who were granted leave during the iddah period had a 'miracle' in their life. She was able to use that time to draw closer to God without going through many trials while praying for her husband's spirits.

This step is in keeping with human nature that is influenced by the inner element of feeling, soul and desire. If these elements are compromised, it will affect behaviours and actions. Wisdom in the field of religion emphasizes that the healing process of depression and other mental problems is spiritual. It is seen as the best alternative to treating these mental illnesses using Quranic verses, offering prayers, recitation, rituals and special prayers, implementing and performing al-ma'aruf prayers as prescribed by Islamic syariah Islam. Islam also advocated through the guidance of the Sunnah of the Prophet (SAW) in the matter of establishing good friendships and social relations in society. The tendency to be alone is a term and a guide to mental illness where there is a lack of assimilation, communication, and sharing of 
aspirations with other people collectively. The close relationships between family members and the surrounding community help to stimulate more balanced thoughts, emotions and feelings, enthusiasm and motivation in pursuing a successful life.

3. The Role of the Authorities and the Surrounding Community

The majority of the respondents suggested that a committee or body be set up to care for women whose husbands have passed away. This proposal is also in line with the suggestion of several researchers to establish a support system that may help this group as a social support action strategy (Clark \& Hamplová, 2013). They suggest single mothers need social support as a measure of reducing the burden on them. In addition, they can learn and apply what they learn from their existing support systems. This social support system is not only focused on family and friends, but it also plays a vital role as an encouragement to single mothers (Clark, 2001). Grossman et al (2009) suggest that social support is important because it is through this support system that single mothers can adapt themselves to a different lifestyle than before.

In the context of Malaysia, the Ministry of Family and Community Development (2014) has developed a system of support for single mothers. Several large-capacity programmes are also being launched across the country to help single mothers live a better life. Among the programs launched by the government are the Creative Fingers and Creative Inspiration Programme held in parliamentary areas with an emphasis on sewing, accessories and embroidery activities; Indigenous Women Programme; The Flower Garden Project in which the farming program provides flowering for the herbal tea industry; A small officehome office programme that allows women to learn skills for three months and have the opportunity to work on their own at home without time constraints. Besides, there was a 'home managers' programme that educates women on all the techniques of managing a home well and professionally; and many other programmes that are of particular benefit to women especially single mothers. The formulation of various programmes by the government and other parties concerned with the issue of poverty among single mothers is essential for creating a wellbalanced society. 
4. Understanding the Law of Iddah in the Current Contexts with Contemporary Elements

The findings of the study also show that $95 \%$ of the respondents suggested that understanding the concept of iddah should take into account the situation that exists for the women as long as it does not violate the prescribed rules. The debate on the laws relating to women whose husbands have passed away has been described in detail in the Quran and Hadith to preserve the good and to ensure that they can continue their lives well after the death of the husband. However, most scholars have warranted that they be given the freedom to leave their homes in need (Taqy al-D in Ab i Bakr Muhammad al-Husayni, n.d.). Therefore, the needs of the devout are to be considered in the practice of iddah (Al-Zuhayli, 1997). This view is relevant and in line with current reality ('Al i 'Abd al-Hal i m Mahmud, 2003). So also the women are allowed to move out of the husband's home to other place which is considered safer for herself and her property (Wazarahal awqaf, 1983). This view is relevant and in keeping with current reality. The need to work on personal and childcare needs greatly hinders a woman who is struggling to get out of the house during the iddah period ('Al i' Abd al-Hal im Mahmud, 2003). They can also manage household affairs and out-of-home matters such as meeting the basic needs of the family, managing children's schooling and so on (Sh. Noorul Madihah Syed Husin, 2007).

\section{CONCLUSION}

The sacred marriage bond will be fulfilled by the dissemination of the concept of iddah. Thus, the scholars and the four imams of the mazhabs concluded that the rules of Iddah were intended to express sorrow and to fulfill the promise of the sacred bondage. All parties are responsible, either directly or indirectly, to ensure that women whose husbands die can lead a more peaceful and organized life to avoid slander and persecution against women. The knowledge pertaining to women's fiqh especially on the issue of iddah needs to be learned and understood by members of the public in order to understand the concept of mourning and being in the state of sorrow according to the real demands of Islam. A true understanding of iddah can 
also avoid a negative perception of the concept. The knowledge of women's fiqh especially on the issue of iddah needs to be learned and understood by members of the public so that the concept of iddah and mourning in accordance with the true demands of Islam can be understood. A true understanding of iddah can also avoid negative perception on the concept of iddah. The study also showed that the level of respondents' understanding of the message needs to be improved. Therefore, the findings are expected to provide input to various stakeholders to increase the level of understanding of the Muslim community in general and Muslim women in particular on this issue in order to realize one of the laws which have been detailed in the Quran and Sunnah.

\section{ACKNOWLEDGEMENT}

We thank the Universiti Teknologi MARA for the financial support through LESTARI Grant Vote No: 600-IRMI/Dana KCM 5/3/LESTARI (185/2017).

\section{REFERENCES}

'Abd al-Wahab Khalaf, (1956). 'Ilm U sul al-Fiqh, cet. 8. Kaherah: Maktabah al-Da'wah al-Islamiyyah,199

Abd al-Karim Zaidan, (2000). Al-Mufassal fi Ahkam al-Mar'ah wa al-Bait al-Muslim fi al-Shari' ah al-Islamiyyah. Juz. 9. Beirut: Mu'assasah alRisalah.

Abu al-Fida' al Hafiz Ibn Kathir, (1998). Tafsir al Quran j.1. cet.2. Beirut: Dar al- Fikr

Abu Muhammad Al Ibn Ahmad Ibn Hazm (n.d.) al-Muhalla, juz. 10. Beirut: Dar al-Fikr

Abu Zakariyya Yahya Syarf al Nawawi, (2001). Sahih Muslim bi Syarh alNawawi Kita b al-Qadr, Ba b Kayfiyyah al-Khalq al-Adam i f i batn Ummih waKita bah Rizqih wa Ajalih wa 'Amalih wa Syaqawatih wa Sa'adatih, no. Hadith 2643, j. 16. T.T.P: Dar al-Taqwa 
Journal of Contemporary Islamic Studies

Ali Abd Halim Mahmud, (2003). al-Mar'ah al-Muslimah wa Fiqh al-Da 'wah ila Allah Juz. 4, cet. 5. Beirut: Dar al-Fikr

Al Mughni, Ibnu Qudamah, (1413H). Tahqiq Abdul Muhsin bin Abdullah Al Turki dan Abdul Fattah bin Muhammad Al Halwu, cet. 2, Penerbit Hajar, Cairo

Chua, B. S. (2007). Stres dalam Kalangan Ibu Tunggal. Sabah: Penerbit UMS.

Denise Boyd \& Helen Bee, (2009). Lifespan Development. USA: Pearson International Edition

Dharatun Nissa Binti Puad Mohd Kari, (2017). Strategi Daya Tindak Dalam Kalangan Ibu Tunggal Kematian Pasangan (Doctor of Philosophy), Universiti Malaya Kuala Lumpur

Dasimah, O., Puziah, A., \& Muna, S. (2009). Urban Living Condition of Low Income Single Mothers in Malaysia. European Journal of Social Sciences, 9(2).

Dr. Teuku Iskandar, (2007). Kamus Dewan edisi keempat. Kuala Lumpur, Dewan Bahasa dan Pustaka

Glade B. Curtis, (1994). Your Pregnancy Week by Week. Singapura: Fisher Books.

Michele Isaacs Gliksman \& Theresa Foy DiGeronimo (1999). The Complete Idiot's Guide to Pregnancy and Childbirth. New York: Alpha Books

Hamdan, A. K. (2008). Kesan Latihan Ketegasan terhadap Tegas Diri dan Konsep Kendiri di kalangan Ibu Tunggal di Johor Bharu. (Doctor of Philosophy), Universiti Teknologi Malaysia.

Ibn al-Jauzi, Imam Jalal al-Din Abi al-Farj. (1998). Ahkam al-Nisa'. Beirut: Dar al-Ma'rifah.

Jurnal Syariah Jil. 18, Bil. 3 (2010). 479-506. 
Kamarul Azmi Jasmi et al. (2004). "Permasalahan Ibu Tunggal Dalam Melaksanakan Tanggungjawab Pendidikan Anak-anak: Satu Kajian Kawasan Sura, Dungun, Terengganu" (Kertas Kerja Seminar Pembangunan Keluarga Kebangsaan 2004 di Universiti Malaya pada 23-30 Mei 2004).

Kementerian Pembangunan Wanita, K. D. M. (2015). Pelan Tindakan Pemerkasaan Ibu Tunggal 2015-2020. In K. D. M. Kementerian Pembangunan Wanita (Ed.). Putrajaya.

Kementerian Pembangunan Wanita dan Keluarga dan Masyarakat. (2014). Quick Facts KPWKM. Kuala Lumpur Malaysia.

Mohd.Hamim Rajikin,(1998). Kehamilan Bermulanya Satu Kehidupan. Kuala Lumpur:Dewan Bahasa dan Pustaka.

Muhammad Al Hamuud Al Najdi, (1415H). Al Kalimaat Al Bayyinaat Fi Ahkam Hadaad Al Mukmina, cet. 1, Dar Al Fath.

Parkes \& Prigerson, (2010). Bereavement. Studies on Grief in Adult Life. London: Routledge.

Sa'ad Yusuf Mahmud Abu 'Az i z (n.d.), A $d$ ab al-H aah al-Zawjiyyah $f$ ial-Isl am. Kaherah: ktabah al-Tawf i qiyyah.

Sh Noorul Madihah Syed Husin et al. (2008). "Tuntutan al-Quran TerhadapWanita Kematian Suami: Satu Penelitian" (Kertas Kerja Seminar al-Quran dan Pembentukan Ummah Cemerlang di Universiti Darul Iman Malaysia pada 19-20 Ogos 2008).

Sh. Noorul Madihah Syed Husin, (2007). "Kefahaman Masyarakat Islam Tentang Iddah: Kajian di Bandar Dungun, Terengganu", Disertasi Sarjana Syariah, JabatanFiqh dan Usul, Akademi Pengajian Islam, Universiti Malaya.

S.S. Datuk Dr. Zulkifli Bin Mohamad Al-Bakri Mufti Wilayah Persekutuan (Bayan Linnas) 
Journal of Contemporary Islamic Studies

Taqy al Din Abi Bakr Muhammad al- Husayni (n.d.). Kifayah al-Akhyar Lill Ghayah al-Ikhtisar, jil.2. Beirut: Dar al-Kutub al-'Ilmiyyah

Wahbah al-Zuhaily, (1997). Al-Fiqh al-Islami wa Adillatuh. Juz. 9. Beirut: Dar al-Fikr.

Wazarah al-Awqaf wa al-Syu'un al-Islamiyyah, (1983). al-Mawsu'ah alFiqhiyyah, juz. 2, cet. 2. Kuwait: Wazarah al-Awqaf wa al-Syu'un alIslamiyyah.

ZaadAlMa'adFiHadyu Khoirul Ibad,IbnuAlQayyim,(1421H). Tahqiq Syu'aib Al Arnauth dan Abdul Qadir Al Arnauth, cet.3, Muassasah Al Risalah http://www.utusan.com.my/rencana/utama/hati-hati-kemurungandalam-masyarakat-1.720281\#ixzz5iPp2KuPV (C Utusan Melayu(M) Bhd 27 Mac 2018...Kosmo Online. 